- R. Szpyra zaprezentował wybrane aspekty militarnego reagowania na terroryzm jako zagrożenie asymetryczne;

- K. Kraj przybliżył niektóre kwestie dotyczące rozwoju technologii terrorystycznych;

- W. Stankiewicz przedstawił cyberterroryzm jako ważne zagrożenie asymetryczne współczesnego świata;

- W. Nowiak przeanalizował drugą wojnę libańską w kontekście terroryzmu i asymetrii;

- D. Szlachter opisał politykę informacyjną administracji państwowej w walce z terroryzmem na przykładzie Zjednoczonego Królestwa, a szczególnie podmioty i cele tej polityki.

Nawiązując do treści wstępu zawartej na s. 6, należy podkreślić, iż w recenzowanej pracy wskazano, że „Asymetryczność to pewien model konstruowania i opisu świata, mniej lub bardziej popularny, ale uniwersalny. Świat byl, jest i będzie asymetryczny. I nie odmieni tego integracja czy globalizacja. Co najwyżej zmienić się może zakres i skala asymetryczności’'. Stwierdzenie to można w znacznym stopniu odnosić do rozważań prowadzonych nie tylko w skali światowej, ale także innej międzynarodowej, narodowej (krajowej), regionalnej i lokalnej.

Wśród innych walorów ocenianej publikacji trzeba między innymi wymienić: dążenie do zaprezentowania interdyscyplinarnego ujęcia, wysoką aktualność rozważań, uwzględnianie aspektów teoretycznych i praktycznych, przedstawianie danych empirycznych, wykorzystywanie w rozważaniach dotąd opublikowanych merytorycznych pozycji literatury, w tym prac anglojęzycznych. Wydaje się, że omawiana praca może także stanowić inspirację do prowadzenia dalszych badań nad tą niezwykle ważną tematyką. Wiele wątków warto kontynuować w ramach kolejnych badań i publikacji.

Można również zauważyć, że ogólnie książka została starannie opracowana pod względem redakcyjno-technicznym.

Reasumując należy stwierdzić, że recenzowana publikacja jest wartościowym wkładem do badań nad problematyką bezpieczeństwa międzynarodowego. Może być użyteczna dla teoretyków i praktyków, również studentów i dyplomantów, zajmujących się różnymi dziedzinami, przede wszystkim politologią, stosunkami międzynarodowymi, globalizacją, studiami strategicznymi, bezpieczeństwem narodowym, ekonomia.

Ireneusz JAŹWIŃSKI

Uniwersytet Szczeciński

\title{
Malgorzata Budyta-Budzyńska, Socjologia narodu $i$ konfliktów etnicznych, Wydawnictwo Naukowe PWN, Warszawa 2010, ss. 317.
}

Problematyka narodowościowa w minionych dwóch dekadach stanowiła w mniejszym lub większym stopniu obiekt zainteresowania badaczy stosunków międzynarodowych, głównie za sprawą krwawych konfliktów etnicznych na Bałkanach i w Afryce, nacjonalistycznych resentymentów w Europie Środkowej i Wschodniej oraz ruchów separatystycznych w Europie Zachodniej czy Azji. Do ich zrozumienia i analizy potrzebna była teoretyczna wiedza z różnych dziedzin, związana z kwestiami etnicznymi, do tej pory „,rozsiana" po licznych publikacjach. W latach dziewięćdziesiątych XX w. polscy czytelnicy mogli zapoznać się z zachodnimi poglądami na tematykę etniczną dzięki thumaczeniom 
prac m.in. Ernesta Gellnera, Rogersa Brubakera czy Benedicta Andersona, na ten temat pisali też polscy naukowcy, np. Jerzy Szacki, Antonina Kłoskowska, Marek Waldenberg lub Piotr Eberhardt. Brak było jednak jednej pozycji, która mogłaby wprowadzić czytelnika w zagadnienia związane z socjologią narodu. Taką funkcję może dziś spełniać książka Małgorzaty Budyty-Budzyńskiej Socjologia narodu i konfliktów etnicznych.

Socjologia narodu... stanowi efekt działalności dydaktycznej Autorki i została wydana w serii podręcznikowej PWN dotyczącej różnych działów socjologii, co jest o tyle ważne, iż na polskim rynku trudno jest znaleźć podobną publikację, poruszającą tematykę etniczną w tak szeroki sposób i do tego aktualna, uwzględniającą najnowsze badania i publikacje. To przeznaczenie książki określa kryteria jej oceny i przydatności.

Jak zastrzega Autorka, książka ma charakter wprowadzający, toteż nie wyczerpuje w pelni niezwykle bogatej tematyki etnicznej. Zostały w niej przedstawione w syntetyczny sposób główne zagadnienia, dające ogólny obraz tej dziedziny i punkt wyjścia do zgłębiania poszczególnych kwestii. W podręczniku brakuje jednak kilku istotnych elementów: nie zostały omówione główne teorie nacjonalizmu, poruszając kwestię konfliktów etnicznych Autorka nie nawiazała do publikacji Donalda Horowitza, jednego z najważniejszych ekspertów w tej dziedzinie. Kontrowersyjne może być zaliczenie różnych konfliktów międzypaństwowych do kategorii zewnętrznych konfliktów etnicznych. Ponadto w przypadku niektórych przykladów pojawiają się czasem drobne nieścislości. Natomiast na docenienie zasługuje wykorzystanie dorobku twórców z byłej Jugosławii czy ukazanie sposobów badania i przezwyciężania stereotypów. $Z$ punktu widzenia badaczy stosunków międzynarodowych także ciekawy może być rozdzial poświęcony państwu narodowemu w dobie globalizacji.

Książka podzielona jest na 10 rozdziałów poświęconych następującym zagadnieniom:

- naród, problemy definicyjne, etniczna i obywatelska koncepcja narodu;

- proces narodotwórczy, jego dwie odmiany - wschodnia i zachodnia, czynniki narodotwórcze;

- tożsamość narodowa na tle innych tożsamości, procesy kształtowania i ewolucji tożsamości;

- stereotypy, ich funkcja i przyczyny powstawania, możliwości badania oraz przezwyciężania;

- mniejszości narodowe, kwestie definicyjne, systemy ochrony oraz katalogi praw, polityka narodowościowa;

- nacjonalizm, znaczenie i składniki pojęcia, różne sposoby pojmowania, funkcje, przyczyny nacjonalizmu w Europie Środkowo-Wschodniej;

- konflikt etniczny wraz z typologią konfliktów etnicznych.

Każdy rozdzial ma podobną strukturę: rozpoczynają go pytania, które wskazują na główne problemy, wprowadzenie, treść merytoryczna, podsumowanie oraz słowniczek wybranych terminów. Publikacja ma charakter interdyscyplinarny - poruszane są w niej zagadnienia nie tylko z zakresu socjologii, ale także psychologii społecznej, politologii, stosunków międzynarodowych oraz prawa.

Na szczególną uwagę zasługują przykłady, których w publikacji jest bardzo dużo, co nie tylko ułatwia zrozumienie tematyki, ale wzbogaca treść i zaciekawia czytelnika. Niektóre zagadnienia szczegółowe, powiązane z tematyką podrozdziałów zostały omówione w tzw. ramkach, co dodatkowo zwiększa atrakcyjność książki. Jedyne zastrzeżenie można odnieść do dobru tematyki owych przykładów. M. Budyta-Budzyńska we wstępie pisze, że koncen- 
truje się głównie na problematyce europejskiej, a zwłaszcza środkowo- i wschodnioeuropejskiej (choć nie brak też odniesień do innych kontynentów), co należy uznać za słuszne, choćby ze względu na wzrost napięć na tle narodowościowym w tym regionie, jednak trzeba jednocześnie pamiętać, że tematyka etniczna nie ogranicza się współcześnie do Starego Kontynentu. Tragiczne w skutkach konflikty etniczne na Bałkanach miały miejsce w latach dziewięćdziesiątych XX w. oraz na początku XXI w., po tym czasie napięcia pojawiały się już rzadziej (choć są obecne do dziś). Prezentowane w książce bałkańskie przykłady wskazują na dużą znajomość tematu, rozszerzają wiedzę czytelnika i dobrze ilustrują opisywane zjawiska. Współcześnie jednak wiele poważnych konfliktów etnicznych ma miejsce w Azji i Afryce (jak np. konflikt w Sudanie, który doprowadził do referendum w styczniu 2011 r.). Ich wyjaśnienie wymaga zrozumienia lokalnej specyfiki, która w polskiej literaturze jest prezentowana stosunkowo rzadko.

Podręcznik oparty jest o bogatą literaturę, zarówno autorów polskich, jak i zagranicznych (głównie anglosaskich). Znajdują się tutaj odniesienia do klasycznych pozycji, ale także do najnowszych wydawnictw, dzięki czemu czytelnik może zapoznać się z aktualnym stanem badań i dyskutowanymi obecnie teoriami. Autorka wykorzystuje także swoje wcześniejsze prace, w rozdziale dotyczącym nacjonalizmu w Europie Środkowo-Wschodniej prezentuje interesująca, autorską koncepcję przyczyn występowania tego zjawiska w oparciu o trzy różne perspektywy czasowe. Nawiązuje także do swojej książki poświęconej mniejszościom narodowym w Polsce pt. Mniejszości narodowe - bogactwo czy problem? Instytucjonalizacja mniejszości narodowych w Polsce w latach 1989-2002.

Język publikacji jest jasny i zrozumialy. Autorka posługuje się terminologią naukową w sposób przystępny, wyjaśniając nowe i mniej zrozumiałe pojęcia. Warto zwrócić uwage, że narracja prowadzona jest w sposób żywy i odrobinę lżejszy niż w klasycznych publikacjach naukowych, dzięki czemu książka staje się bardziej przystępna dla czytelnika nieposiadającego zbyt szerokiej wiedzy z zakresu socjologii czy psychologii społecznej.

Podsumowując, należy stwierdzić, iż publikacja M. Budyty-Budzyńskiej stanowi cenną nowość na polskim rynku z dwóch powodów. Po pierwsze, jest to nowoczesny podręcznik, wprowadzający w przystępny i ciekawy sposób do problematyki narodowościowej. Po drugie, prezentuje on najnowszy stan badań, uwzględniający pozycje polskie i zagraniczne, przez co czytelnik otrzymuje dość kompleksową wiedzę z omawianej dziedziny. Można oczywiście dopatrzeć się niewielkich mankamentów, które jednak nie rzutują na pozytywną ocenę publikacji. Choć jest ona rekomendowana jako podręcznik dla studentów nauk społecznych, to może również służyć badaczom, którzy wcześniej nie interesowali się tą tematyką jako punkt wyjścia do dalszych szczegółowych badań. Wreszcie książka może służyć też każdemu, kto chciałby lepiej poznać świat narodów i nacjonalizmów.

Marcin SKOBRTAL

Uniwersytet im. Adama Mickiwicza, Poznań 